\title{
KINERJA PENYULUH PERTANIAN PADA KELOMPOK TANI PADI SAWAH DESA KOPIWANGKER KECAMATAN LANGOWAN BARAT
}

\author{
Livia Salu \\ Eyverson Ruauw \\ Vicky R.B. Moniaga
}

\begin{abstract}
The purpose of this research is to know the performance of agriculture extension workers in wetland paddy farmer group in Kopiwangker Village, West Langowan Sub-district, Minahasa District. This research was conducted for 5 months from November 2016 until March 2017. This research uses primary data and secondary data. This research was conducted by direct interview technique, based on the prepared questionnaire to three farmer groups. They are Suka Maju Farmer Group, Esa Group and Tumou Tou farmer group. Each groups taken 3 respondents and 2 members from BP3K so total respondents are 11 people. The results showed that the level of agricultural extension performance in the farmer group in Desa Kopiwangker was quite good in relation to the seven tupoksi studied were the area potential data, the agricultural extension program, the information disseminated to the main actors, the growth of the farmer institution, the increased capacity of the main actors, Key actors of market information, technology and financing and increased production and revenue of key players.
\end{abstract}

Keywords: extension worker, farmer group, Kopiwangker Village, Langowan Barat Sub-districts, Minahasa District

\begin{abstract}
ABSTRAK
Tujuan dari penelitian ini untuk mengetahui kinerja penyuluh pada kelompok tani padi sawah di Desa Kopiwangker, Kecamatan Langowan Barat, Kabupaten Minahasa. Penelitian ini dilaksanakan selama 5 bulan yaitu dari bulan November 2016 sampai bulan Maret 2017. Penelitian ini menggunakan data primer dan data sekunder. Penelitian ini dilakukan dengan teknik wawancara langsung pada tiga kelompok tani yaitu kelompok tani Suka Maju, Esa Keter dan Tumou Tou masing-masing 3 sebanyak responden dan 2 anggota dari BP3K, berdasarkan daftar pertanyaan yang telah disiapkan. Total responden 11 orang. Hasil penelitian menunjukan bahwa tingkat kinerja penyuluh pertanian pada kelompok tani di Desa Kopiwangker tergolong cukup baik berkaitan dengan ketujuh tupoksi yang diteliti yaitu data potensi wilayah, program penyuluh pertanian, terdesiminasi info pada pelaku utama, tumbuh kembangnya kelembagaan petani, meningkatnya kapasitas pelaku utama, meningkatnya akses pelaku utama terhadap info pasar, teknologi dan pembiayaan dan meningkatnya produksi dan pendapatan pelaku utama.
\end{abstract}

Kata kunci : kinerja penyuluh, kelompok tani, Desa Kopiwangker, Kecamatan Langowan Barat, Kabupaten Minahasa 


\section{PENDAHULUAN}

\section{Latar Belakang}

Pertanian merupakan komponen utama yang menopang kehidupan pedesaan di Indonesia. Pertanian tidak hanya sebatas pertanian dalam artian yang sempit, namun dalam arti yang luas yakni menghasilkan produk primer yang terbaru, termasuk di dalamnya pertanian tanaman pangan dan holtikultura, perkebunan, peternakan, perikanan dan kehutanan. Jadi sektor pertanian adalah sektor yang mau tidak mau harus ada dan berkembang, karena bukan hanya urusan pendapatan negara tapi juga kelangsungan hidup manusia. Semua usaha pertanian pada dasarnya adalah kegiatan ekonomi sehingga memerlukan dasar-dasar pengetahuan yang sama akan pengelolaan tempat usaha, pemilihan benih/bibit, metode budidaya, pengumpulan hasil, distribusi produk, pengolahan, pengemasan produk, dan pemasaran.

Seorang petani memandang semua aspek ini dengan pertimbangan efisiensi untuk mencapai keuntungan maksimal maka harus melakukan pertanian intensif (intensive farming). Program dan kebijakan yang mengarahkan usaha pertanian ke cara pandang demikian dikenal sebagai intensifikasi. Karena pertanian industrial selalu menerapkan pertanian intensif, keduanya sering di samakan. Sisi yang bersebrangan dengan pertanian industrial adalah pertanian berkelanjutan (sustainable agriculture) Departemen Pertanian, (2007).

Mardikanto (2003), melalui penyuluhan Pertanian masyarakat pertanian dibekali dengan ilmu pengetahuan, ketrampilan, pengenalan paket teknologi dan inovasi baru di bidang pertanian dengan usahanya, penanaman nilainilai atau prinsip agribisnis, mengkreasi sumber daya manusia dengan konsep dasar filosofi rajin, kooperatif, inovatif, kreatif dan sebagainya. Penyuluh pertanian dapat dan harus mengunakan teknik-teknik komunikasi yang paling efektif agar sasaran mau menerapkan pengetahuan barunya. Melalui komunikasi yang efektif dapat menunjang keberhasilan penyuluhan pertanian.

Menurut Bernardin \& Russel (Mardikanto 1993), mendefenisikan kinerja sebagai catatan outcome yang dihasilkan dari fungsi pegawai tertentu. Kontribusi anggota organisasi terhadap organisasinya dapat diukur dengan penilaian kinerja kerja. Sedangkan Kusnadi mendefenisikan kinerja sebagai setiap gerakan perbuatan, pelaksanaan, kegiatan atau tindakan sadar yang diarahkan untuk mencapai suatu tujuan atau target tertentu. Tanpa adanya kinerja berarti tidak ada upaya untuk mencapai hasil atau target dan tidak akan terjadi suatu perubahan sedikitpun. Dari kualitas kinerja nantinya akan berpengaruh kepada hasil. Kinerja yang baik memiliki beberapa karakteristik yaitu: rasional, konsisten, tepat, efisien, tertantang, terarah, disiplin, sistematis, dapat dicapai, disepakati, terkait dengan waktu dan beorientasi pada kerjasama kelompok. Jadi dapat disimpulkan bahwa kinerja merupakan implementasi dari rencana yang telah disusun. Implementasi kinerja dilakukan oleh sumber daya manusia yang memiliki kemampuan, kompetensi, motivasi dan kepentingan. Bagaimana organisasi menghargai dan memperlakukan sumber daya manusianya akan mempengaruhi sikap dan perilakunya dalam menjalankan kinerja. Penyelengaraan penyuluhan pertanian di tingkat lapangan harus sesuai dengan kebutuhan pelaku utama dan pelaku usaha melalui program pembangunan pertanian secara luas yang diturunkan oleh dinas lingkup pertanian agar tidak terjadi benturan kebutuhan tingkat lapangan sehingga semuanya dapat dilaksanakan dengan baik sesuai tujuan pelaksanaan program tersebut. Dilapangan menunjukan peran penyuluh pertanian kurang aktif dalam melakukan pengunjugan pada kelompok binaan. Tugas penyuluh pertanian selain membina petani, juga menyusun program, laporan kegiatan per bulan, membuat rencana kebutuhan petani, mengikuti latihan kegiatan binaan yang dilakukan dikabupaten. Kegiatan penyuluh pertanian pada kelompok tani yaitu, cara pembasmian hama, jarak tanam padi jajar legowo, pembibitan padi unggul. Satu orang tenaga penyuluh membina lima sampai enam desa.

Berdasarkan survey ada 3 kelompok tani yang terbentuk di Desa Kopiwangker yaitu Tumou Tou, Esa Keter dan Kelompok Tani Suka Maju. Kelompok Tani yang ada di Desa Kopiwangker tidak luput dari penyuluh 
pertanian yang berada di BP3K (Balai Penyuluhan Pertanian, Perikanan dan Kehutanan) dan jumlah penyuluh di Kecamatan Langowan Barat tiga orang. Untuk mengetahui kinerja penyuluhan pertanian di tingkat lapangan maka perlu dilakukan penelitian terhadap penyuluh pertanian. Dengan melakukan penelitian ini akan terlihat keberhasilan dan kekurangan dari kinerja penyuluh pertanian yang telah dilakukan dan menjadi bahan masukan pada penyuluh pertanian untuk selanjutnya.

\section{Rumusan Masalah}

Berdasarkan latar belakang, yang menjadi rumusan masalah dalam penelitian ini ialah bagaimana kinerja penyuluh pada kelompok tani padi sawah yang ada di Desa Kopiwangker Kecamatan Langowan Barat?

\section{Tujuan Penelitian}

Penelitian ini bertujuan untuk mengetahui kinerja penyuluh pada kelompok tani padi sawah di Desa Kopiwangker Kecamatan Langowan Barat.

\section{Manfaat Penelitian}

Manfaat penelitian ini yaitu sebagai sumber ilmu pengetahuan tentang kinerja penyuluh pertanian. Diharapkan kepada para pembaca untuk mendapat pengetahuan tentang kinerja penyuluh pertanian pada kelompok tani padi sawah. Penulisan ini juga diharapkan dapat menjadi bahan studi referensi untuk penulispenulis salanjutnya dan referensi dalam melaksanakan penelitian selanjutnya.

\section{METODOLOGI PENELITIAN}

\section{Lokasi dan Waktu Penelitian}

Penelitian ini dilaksanakan di Desa Kopiwangker Kecamatan Langowan Barat pada 3 Kelompok Tani yaitu kelompok tani Suka Maju, Esa Keter dan kelompok tani Tumou Tou. Penelitian ini berlangsung selama 5 bulan mulai dari bulan November 2016 sampai Maret 2017.

\section{Metode Pengumpulan Data}

Penelitian ini menggunakan data primer dan data sekunder. Data primer diperoleh melalui wawancara langsung pada kelompok tani Suka Maju, Esa Keter kelompok tani Tumou Tou masing-masing 3 responden dan 2 anggota dari BP3K, berdasarkan daftar pertanyaan yang telah disiapkan (kuesioner), sedangkan data sekunder diperoleh melalui instansi-instansi yang berkaitan dengan penelitian ini antara lain kantor BP3K Kecamatan Langowan Barat.

\section{Konsep Pengukuran Variabel}

Variabel kinerja penyuluh dapat dilihat dengan menggunakan 7 tupoksi sebagai berikut :

a. Tersusunnya data potensi wilayah

1. Menemukan potensi wilayah

2. Pembuatan peta wilayah kerja

3. Keterlibatan dalam potensi

b. Tersusunnya programa penyuluh pertanian

1. Penyusunan bahan program

2. Pencetakan materi

3. Pelaksanaan program

c. Terdesiminasinya info teknologi pertanian pada pelaku utama.

1. Penyebaran informasi

2. Kunjungan/tatap muka

3. Melakukan Metode penerapan dalam bentuk demonstrasi

d. Tumbuh kembangnya kelembagaan petani.

1. Kelompok tani pemula ke lanjut

2. Pengembangan jumlah kelompok tani

3. Peningkatan ketrampilan kelompok tani

e. Meningkatnya kapasitas pelaku utama.

1. Jumlah anggota yang mengikuti latihan

2. Peningkatan kualitas dan kuantitas demplot

3. Peningkatan kesejahtraan petani

f. Meningkatnya akses pelaku utama terhadap info pasar, teknologi dan pembiayaan.

1. Pembentukan jejaring antar kelompok tani

2. Memberi info pasar

3. Pengembangan kemitraan

g. Meningkatnya produksi meningkatnya pendapatan pelaku utama.

1. Peningkatan produksi

2. Peningkatan pendapatan kelompok tani

3. Peningkatan pendapatan keluarga kelompok tani

\section{Metode Analisis Data}

Metode analisis data yang digunakan dalam penelitian ini adalah skala likert menurut 
Soegiyono dalam Sunyoto (2014), skala likert adalah skala yang digunakan untuk menggukur sikap, pendapat atau kelompok orang tentang fenomena seseorang. Skala likert, variabel yang akan diukur dijabarkan menjadi indikator variabel. Dan indikator tersebut dijadikan sebagai titik tolak untuk menyususn item-item instrument yang dapat berupa tupoksi. Dalam penelitian ini disusun 21 tupoksi.

$\mathrm{B}=$ Baik

$\mathrm{CB}=$ Cukup Baik

$\mathrm{TB}=\mathrm{T}$ idak Baik

Bila :

B diberi skor $=3$

$\mathrm{CB}$ diberi skor $=2$

TB diberi skor $=1$

a. Tersusunnya data potensi wilayah

1. Menemukan potensi wilayah

PPL menemukan potensi wilayah (baik) Petani menemukan (cukup baik) PPL tidak menemukan (tidak baik)

2. Pembuatan peta wilayah

PPL membuat peta (baik) PPL cukup baik membuat peta (cukup baik) PPL tidak membuat peta wilayah (tidak baik)

3. Keterlibatan dalam potensi

PPL terlibat dalam potensi (baik) PPL cukup bai terlibat dalam potensi (cukup baik) PPL tidak terlibat dalam potensi (tidak baik)

b. Program penyuluh pertanian

4. Penyusunan bahan program

PPL membuat penyusunan bahan program (baik), PPL cukup baik membuat bahan program (cukup baik), PPL tidak membuat bahan program (tidak baik)

5. Pencetakan materi

PPL mencetak materi (baik), PPL cukup baik mencetak materi (cukup baik), PPL tidak mencetak materi (tidak baik)

6. Pelaksanaan program

PPL melaksanakan program (baik), PPL cukup baik melaksanakan program (cukup baik), PPL tidak melaksanakan program (tidak baik).

c. Terdesiminasinya infoteknologi pertanian pada pelaku utama

7. Penyebaran informasi

PPL melakukan penyebaran infromasi (baik), PPL cukup baik melakukan penyebaran informasi (cukup baik), PPL tidak melakukan penyebaran informasi (tidak baik).

8. Melakukan kunjungan pada kelompok tani PPL melakukan kunjungan pada kelompok tani (baik), PPL cukup baik melakukan kunjungan pada kelompok tani (cukup baik), PPL tidak melakukan kunjungan pada kelompok tani (tidak baik).

9. Melakukan metode penerapan dalam bentuk demonstrasi

PPL melakukan metode penerapan dalam bentuk demonstrasi (baik), PPL cukup baik melakukan metode penerapan dalam bentuk demonstrasi (cukup baik), PPL tidak melakukan metode penerapan dalam bentuk demonstrasi (tidak baik).

d. Tumbuh kembangnya kelembagaan petani

10. Dari kelompok tani pemula ke kelas lanjut PPL melaksanakan peningkatan kelas kelompok tani (baik), PPL cukup baik melaksanakan peningkatan kelas kelompok tani (cukup baik), PPL tidak melaksanakan peningkatan kelas kelompok tani (tidak baik).

11. Pengembagan jumlah kelas kelompok tani PPL mengembangkan jumlah kelas kelompok tani (baik), PPL cukup baik mengembangkan jumlah kelas kelompok tani (cukup baik), PPL tidak mengembangkan jumlah kelas kelompok tani (tidak baik).

12. Peningkatan keterampilan kelompok tani PPL meningkatkan keterampilan kelompok tani (baik), PPL cukup baik meningkatkan keterampilan kelompok tani (cukup baik), PPL tidak meningkatkan keterampilan kelompok tani (tidak baik).

e. Meningkatnya kapasitas pelaku utama

13. Jumlah anggota yang mengikuti pelatihan PPL mengembangkan jumlah anggota yang mengikuti pelatihan (baik), PPL cukup baik mengembangkan jumlah anggota yang mengikuti pelatihan (cukup baik), PPL tidak mengembangkan jumlah anggota yang mengikuti pelatihan (tidak baik).

14. Peningkatan kualitas dan kuantitas demplot

PPL meningkatkan kuantitas dan kualitas demplot (baik), PPL cukup baik meningkatkan kuantitas dan kualitas demplot (cukup baik), PPL tidakmeningkatkan kuantitas dan kualitas demplot (tidak baik). 
15. Peningkatan kesejahteraan petani

PPL meningkatkan kesejahteraan petani (baik), PPL cukup baik meningkatkan kesejahteraan petani (cukup baik), PPL tidak meningkatkan kesejahteraan petani (tidak baik).

f. Meningkatnya akses pelaku utama terhadap info pasar, teknologi dan pembiayaan

16. Pembentukan jejaring antar kerja kelompok tani

PPL terlibat dalam pembentukan jejaring antar kerja kelompok tani (baik), PPL cukup baik terlibat dalam pembentukan jejaring antar kerja kelompok tani (cukup baik), PPL tidak terlibat dalam pembentukan jejaring antar kerja kelompok tani (tidak baik).

17. Memberi informasi pasar

PPL memberi informasi pasar (baik), PPL cukup baik memberi informasi pasar (cukup baik), PPL tidak memberi informasi pasar (tidak baik).

18. Pengembagan kemitraan

PPL melakukan pengembagan kemitraan (baik), PPL cukup baik melakukan pengembagan kemitraan (cukup baik), PPL tidak melakukan pengembagan kemitraan (tidak baik).

g. Meningkatnya produksi dan meningkatnya pendapatan pelaku utama

19. Peningkatan produksi

PPL terlibat dalam peningkatan produksi (baik), PPL cukup baik terlibat dalam peningkatan produksi (cukup baik), PPL tidak terlibat dalam peningkatan produksi (tidak baik).

20. Peningkatan pendapatan kelompok tani PPL melakukan peningkatan pendapatan kelompok tani (baik), PPL cukup baik melakukan peningkatan pendapatan kelompok tani (cukup baik), PPL tidak melakukan peningkatan pendapatan kelompok tani (tidak baik).

21. Peningkatan pendapatan keluarga tani PPL terlibat dalam peningkatan pendapatan keluarga tani (baik), PPL cukup baik terlibat dalam peningkatan pendapatan keluarga tani (cukup baik), PPL tidak baik terlibat dalam peningkatan pendapatan keluarga tani (tidak baik).

Dengan cara perhitungan skor masingmasing pernyataan:
Maka jumlah skor tiap kriteria $=$ capaian skor $\mathrm{x}$ jumlah responden.

$\mathrm{S} 3=3 \times 11=33$

$\mathrm{S} 2=2 \times 11=22$

$\mathrm{S} 1=1 \mathrm{x} 11=11$

Jumlah skor ideal untuk setiap pernyataan (skor tertinggi) $=33$ dan jumlah skor terendah 11 .

Cara perhitungan skor keseluruhan untuk mengetahui kinerja penyuluh pertanian:

Jumlah skor seluruh kriteria = capain jumlah skor $\mathrm{x}$ jumlah responden $\mathrm{x}$ instrument pernyataan.

$\mathrm{S} 3=3 \times 11 \times 21=693$

$\mathrm{S} 2=2 \times 11 \times 21=462$

$\mathrm{S} 1=1 \mathrm{x} 11 \times 21=231$

Jumlah skor ideal untuk keseluruhan pernyataan $=693$ (tinggi) dan jumlah skor rendah $=231$

Tingkat Kinerja Penyuluh pertanian =

$\frac{\text { Jumlah Skor Hasil Pengumpulan Data }}{\text { Jumlah Skor Ideal (tertinggi) }} \times 100 \%$

Dengan Interpretasi nilai :

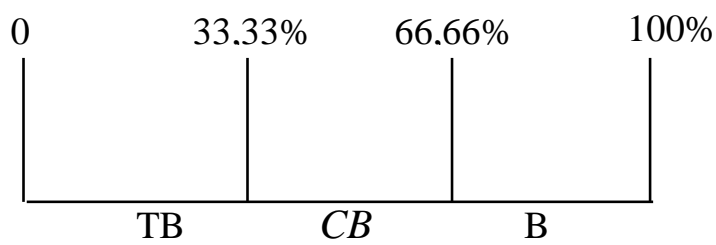

Keterangan kriteria interpretasi skor :

Angka 0\%-33,33\% = Tidak Baik

Angka 33,33\%-66,66\% = Cukup Baik

Angka 66,66\%-100\% = Baik

\section{HASIL DAN PEMBAHASAN}

\section{Deskripsi Wilayah Penelitian}

\section{Letak dan Luas Wilayah}

Desa Kopiwangker adalah salah satu Desa di Kecamatan Langowan Barat, dengan luas wilayah 62 ha yang terdiri dari 4 jaga. Adapun batas-batas desa yaitu:

1. Sebelah utara berbatasan dengan Desa Taraitak.

2. Sebelah selatan berbatasan dengan Desa Lowian.

3. Sebelah barat berbatasan dengan Desa Lowian.

4. Sebelah timur berbatasan dengan Desa Paslaten. 


\section{Jumlah Penduduk}

Jumlah penduduk di Desa Kopiwangker Kecamatan Langowan Barat 1057 jiwa, jumlah penduduk berjenis kelamin laki-laki lebih banyak dibandingkan dengan jumlah penduduk berjenis kelamin perempuan. Hal ini dapat dilihat dari jumlah presentasi laki-laki sebesar $52,13 \%$, perempuan sebesar $47,87 \%$. Dengan jumlah penduduk berjenis kelamin laki-laki sebanyak 551 Jiwa, dan jumlah penduduk berjenis kelamin perempuan 506 Jiwa. Tabel 1 menunjukkan jumlah penduduk Desa Kopiwangker.

Tabel 1. Jumlah Penduduk Desa Kopiwangker

\begin{tabular}{lcc}
\hline Jenis Kelamin & Jumlah Jiwa & Persentase \% \\
\hline Laki-laki & 551 & 52.13 \\
Perempuan & 506 & 47.87 \\
\hline Jumlah & 1057 & 100
\end{tabular}

Sumber : Diolah dari primer, 2017

\section{Mata Pencaharian}

Masyarakat di Desa Kopiwangker Kecamatan Langowan Barat memiliki mata pencarian sebagai petani, pegawai negeri, pedagang, wiraswasta dan lain-lain. Total jumlah penduduk di Desa Kopiwangker Kecamatan Langowan Barat 1057 jiwa. Sedangkan yang memiliki mata pencaharian sebagai petani lebih banyak dari pada pedagang dan PNS, hal ini dapat dilihat dari jumlah persentase yang sebesar $55 \%$, pedagang sebesar 35\%, dan PNS sebesar 10\% dengan jumlah penduduk yang memiliki mata pencaharian sebesar 782 jiwa. Sedangkan 275 jiwa belum memiliki pekerjaan karena terdiri dari anak-anak SD, SMP, SMA dan mahasiswa. Tabel 2 menunjukkan jumlah mata pecaharian penduduk.

Tabel 2. Jumlah Mata Pencaharian Penduduk

\begin{tabular}{lccc}
\hline No & $\begin{array}{c}\text { Mata } \\
\text { Pencaharian }\end{array}$ & Jumlah & Persentase \% \\
\hline 1 & PNS & 79 & $10 \%$ \\
2 & Petani & 432 & $55 \%$ \\
3 & Pedagang & 271 & $35 \%$ \\
\hline & Jumlah & 782 & $100 \%$ \\
\hline
\end{tabular}

Sumber: Diolah dari data primer, 2017

\section{Karateristik Kelompok Tani}

Karakteristik kelompok Tani

Masyarakat di Desa Kopiwangker Kecamatan Langowan Barat. Di antaranya yang pertama kelompok tani suka maju berdiri pada tahun 2002, dengan jumlah anggota sebanyak 23 orang, memiliki luas lahan sebesar 20 ha. Yang kedua kelompok tani Tomou Tou berdiri pada tahun 2006, dengan jumlah anggota 23 orang, memiliki luas lahan sebesar 20 ha. Yang ketiga kelompok tani Esa Keter berdiri pada tahun 2013, dengan jumlah anggota sebanyak 15 orang, memiliki luas lahan 15 ha. Tabel 3 menujukkan karakteristik kelompok tani.

Tabel 3. Karakteristik Kelompok Tani

\begin{tabular}{lcccc}
\hline No & $\begin{array}{c}\text { Kelompok } \\
\text { Tani }\end{array}$ & $\begin{array}{c}\text { Luas } \\
\text { Lahan }\end{array}$ & $\begin{array}{c}\text { Jumlah } \\
\text { Anggota }\end{array}$ & $\begin{array}{c}\text { Tahun } \\
\text { Berdiri }\end{array}$ \\
\hline 1 & Suka Maju & 20 ha & 23 & 2002 \\
2 & Tumou Tou & 20 ha & 23 & 2006 \\
3 & Esa Keter & 15 ha & 15 & 2013 \\
\hline \multicolumn{5}{l}{ Sumber: Diolah dari data primer, 2017 }
\end{tabular}

\section{Umur Responden}

Kemampuan bekerja atau melakukan aktivitas secara fisik seseorang dapat di pengaruhi oleh faktor umur. Setiap responden sudah pasti tidak sama, demikian juga dengan umur dari masing-masing responden, berikut adalah variasi umur dari tiap responden. Tabel 4 menunjukan jumlah responden terbanyak pada umur 41-50 tahun dengan jumlah 5 responden dengan presentasi sebesar $45.45 \%$.

\begin{tabular}{lccc}
\multicolumn{4}{l}{ Tabel 4. Jumlah Responden Menurut Umur } \\
\hline No & $\begin{array}{c}\text { Umur } \\
\text { (Tahun) }\end{array}$ & $\begin{array}{c}\text { Jumlah Responden } \\
\text { Persentase } \\
\%\end{array}$ \\
\hline 1 & $31-40$ & - & - \\
2 & $41-50$ & 5 & 45,45 \\
3 & $51-60$ & 2 & 9,09 \\
4 & $61-70$ & 2 & 9,09 \\
5 & $71-80$ & 2 & 9,09 \\
\hline & Jumlah & 11 & 100
\end{tabular}

\section{Tingkat Pendidikan}

Pendidikan sangat penting dalam usaha peningkatan kualitas penduduk karena berguna bagi pembangunan pribadi serta peningkatan intelektual dan wawasan seseorang. Tingkat pendidikan dari masing-masing orang berbeda, begitu juga dengan tingkat pendidikan dari responden. Tabel 5 menunjukan bahwa tingkat pendidikan responden yang terbanyak yaitu pada pendidikan tingkat SMA dengan jumlah 5 responden dengan presentasi $45.45 \%$ sedangkan tingkat pendidikan paling sedikit dengan tingkat pendidikan SMP dengan jumlah 1 responden dengan presentase $18.18 \%$. Hasil tabulasi atas variabel tersusunnya data potensi wilayah, dapat 
dilihat pada tabel. Penjelasan mengenai tersusunnya data potensi wilayah serta indikator-indikator pendukung akan dipaparkan pada Tabel 5.

\begin{tabular}{lccc}
\multicolumn{4}{c}{ Tabel 5. Jumlah Responden Menurut Tingkat Pendidikan } \\
\hline No & Pendidikan & Jumlah Responden & Persentase $\%$ \\
\hline 1 & SD & 3 & 27,27 \\
2 & SMP & 1 & 9,09 \\
3 & SMA & 5 & 45,45 \\
4 & S1 & 2 & 18,18 \\
\hline 5 & Jumlah & 11 & 100 \\
\hline
\end{tabular}

\section{Kinerja Penyuluh Pertanian Pada Kelompok Tani Padi Sawah}

\section{Tersusunnya data potensi wilayah}

\section{Menemukan potensi wilayah}

Tabel 6 menjelaskan tentangg tupoksi menemukan potensi wilayah. Hasil penelitian ini menunjukan bahwa 100\% responden (11 orang) menyatakan bahwa tupoksi menemukan potensi wilayah bagi kelompok tani tergolong tidak baik, artinya untuk menemukan potensi wilayah yang seharusnya ditemukan oleh penyuluh pertanian, namun ditemukan oleh kelompok tani sendiri selanjutnya akan disampaikan kepada penyuluh pertanian.

\begin{tabular}{lcccc} 
Tabel 6. & Menemukan Potensi Wilayah & & \\
\hline $\begin{array}{l}\text { Alternatif } \\
\text { Jawaban }\end{array}$ & $\begin{array}{c}\text { Alternatif } \\
\text { Skor }\end{array}$ & $\begin{array}{c}\text { Jumlah } \\
\text { Responden } \\
\text { (Orang) }\end{array}$ & $\begin{array}{c}\text { Presentase } \\
\text { Responden } \\
\%\end{array}$ & $\begin{array}{c}\text { Total } \\
\text { Skor }\end{array}$ \\
\hline Baik & 3 & 0 & 0 & 0 \\
Cukup Baik & 2 & 0 & 0 & 0 \\
Tidak Baik & 1 & 11 & 11 & 11 \\
\hline Total & & 11 & 100 & 11 \\
\hline
\end{tabular}

\section{Pembuatan Peta Wilayah Kerja}

Tabel 7 menjelaskan tentang tupoksi pembuatan peta wilayah kerja. Hasil penelitian ini menunjukan bahwa $100 \%$ responden (11 orang), artinya penyuluh pertanian membuat peta wilayah kerja meski tidak semua potensi yang ditemukan dibuat oleh penyuluh pertanian, hal ini dapat diketahui dikantor BP3K ada peta wilayah kerja binaan penyuluh.

\begin{tabular}{lcccc} 
Tabel 7. Pembuatan Peta Wilayah Kerja & \\
\hline $\begin{array}{l}\text { Alternatif } \\
\text { Jawaban }\end{array}$ & $\begin{array}{c}\text { Alterna } \\
\text { tif Skor }\end{array}$ & $\begin{array}{c}\text { Jumlah } \\
\text { Responden } \\
\text { (Orang) }\end{array}$ & $\begin{array}{c}\text { Presentase } \\
\text { Responden } \\
\%\end{array}$ & $\begin{array}{c}\text { Total } \\
\text { Skor }\end{array}$ \\
\hline Baik & 3 & 0 & 0 & 0 \\
Cukup Baik & 2 & 11 & 100 & 22 \\
Tidak Baik & 1 & 0 & 0 & 0 \\
\hline Total & & 11 & 100 & 22 \\
\hline
\end{tabular}

\section{Keterlibatan dalam Potensi}

Pada Tabel 8 menjelaskan tentang tupoksi keterlibatan dalam potensi. Hasil penelitian ini menunjukan bahwa 100\% responden (11 orang). Artinya penyuluh pertanian kurang berpartisipasi untuk melibatkan diri.

Tabel 8. Keterlibatan dalam Potensi

\begin{tabular}{lcccc}
\hline $\begin{array}{l}\text { Alternatif } \\
\text { Jawaban }\end{array}$ & $\begin{array}{c}\text { Alternatif } \\
\text { Skor }\end{array}$ & $\begin{array}{c}\text { Jumlah } \\
\text { Responden } \\
\text { (Orang) }\end{array}$ & $\begin{array}{c}\text { Presentase } \\
\text { Responden } \\
\%\end{array}$ & $\begin{array}{c}\text { Total } \\
\text { Skor }\end{array}$ \\
\hline Baik & 3 & 0 & 0 & 0 \\
Cukup Baik & 2 & 11 & 11 & 22 \\
Tidak Baik & 1 & 0 & 0 & 0 \\
\hline Total & & 11 & 100 & 22 \\
\hline
\end{tabular}

\section{Rekapitulasi Tupoksi tersusunya Data Potensi Wilayah}

Pada Tabel 9 menunjukan bahwa terdapat 3 indikator pembentuk data potensi dimana tupoksi pembuatan peta wilayah kerja dan keterlibatan dalam potensi, mendapat indeks cukup baik yaitu $66,66 \%$ dengan interpretasi cukup baik, sedangkan keterlibatan dalam potensi mendapat indeks kurang baik yaitu $33,33 \%$.

Tabel 9. Rekapitulasi Pengukuran Tupoksi Tersusunnya Data Potensi Wilayah

\begin{tabular}{ccccc}
\hline No & TUPOKSI & $\begin{array}{c}\text { TOTAL } \\
\text { SKOR }\end{array}$ & INDEKS \% & INTERPRESTASI \\
\hline 1 & $\begin{array}{l}\text { Menemukan } \\
\text { Potensi } \\
\text { wilayah }\end{array}$ & 11 & 33,33 & Kurang Baik \\
2 & $\begin{array}{l}\text { Pembuatan } \\
\text { peta wilayah } \\
\text { kerja }\end{array}$ & 22 & 66,66 & Cukup Baik \\
3 & $\begin{array}{l}\text { Keterlibatan } \\
\text { dalam potensi }\end{array}$ & 22 & 66,66 & Cukup baik \\
\hline
\end{tabular}

\section{Tersusunnya Program Penyuluh Pertanian}

\section{Penyusunan Bahan Program}

Pada Tabel 10 menjelaskan tentang tupoksi penyusunan bahan program. Hasil penelitian ini menunjukan bahwa $100 \%$ responden (11 orang). Artinya kelompok tani terbantu dengan adanya bahan program yang dibuat penyuluh pertanian maka tujuan yang akan dicapai diketahui oleh kelompok tani.

\begin{tabular}{lcccc} 
Tabel 10. Penyusunan Bahan Program & & \\
\hline $\begin{array}{l}\text { Alternatif } \\
\text { Jawaban }\end{array}$ & $\begin{array}{c}\text { Alternatif } \\
\text { Skor }\end{array}$ & $\begin{array}{c}\text { Jumlah } \\
\text { Responden } \\
\text { (Orang) }\end{array}$ & $\begin{array}{c}\text { Presentase } \\
\text { Responden } \\
\%\end{array}$ & $\begin{array}{c}\text { Total } \\
\text { Skor }\end{array}$ \\
\hline Baik & 3 & 0 & 0 & 0 \\
Cukup Baik & 2 & 11 & 11 & 22 \\
Tidak Baik & 1 & 0 & 0 & 0 \\
\hline Total & & 11 & 100 & 22 \\
\hline
\end{tabular}




\section{Percetakan Materi}

Pada Tabel 11 menjelaskan tentang tupoksi percetakan materi. Hasil penelitian ini menunjukan bahwa $100 \%$ responden (11 orang). Artinya materi yang diberikan pada kelompok tani terbatas karena mengingat banyak jumlah anggota kelompok tani.

\begin{tabular}{lcccc} 
Tabel 11. Percetakan Materi & & \\
\hline Alternatif & $\begin{array}{c}\text { Alternatif } \\
\text { Jawaban }\end{array}$ & $\begin{array}{c}\text { Jumlah } \\
\text { Responden } \\
\text { (Orang) }\end{array}$ & $\begin{array}{c}\text { Presentase } \\
\text { Responden } \\
\%\end{array}$ & $\begin{array}{c}\text { Total } \\
\text { Skor }\end{array}$ \\
\hline Baik & 3 & 0 & 0 & 0 \\
Cukup Baik & 2 & 11 & 100 & 22 \\
Tidak Baik & 1 & 0 & 0 & 0 \\
\hline Total & & 11 & 100 & 22 \\
\hline
\end{tabular}

\section{Pelaksanaan Program}

Pada Tabel 12 menjelaskan tentang pelaksana tupoksi pelaksanaan program. Hasil penelitian ini menunjukan bahwa $100 \%$ responden (11 orang), artinya dalam pelaksanaan program yang sudah disususun penyuluh pertanian tidak semua program dilaksanakan oleh penyuluh pertanian.

Tabel 12. Pelaksanaan Program

\begin{tabular}{lcccc}
\hline $\begin{array}{l}\text { Alternatif } \\
\text { Jawaban }\end{array}$ & $\begin{array}{c}\text { Alternati } \\
\text { f Skor }\end{array}$ & $\begin{array}{c}\text { Jumlah } \\
\text { Responden } \\
\text { (Orang) }\end{array}$ & $\begin{array}{c}\text { Presentase } \\
\text { Responden } \\
\%\end{array}$ & $\begin{array}{c}\text { Total } \\
\text { Skor }\end{array}$ \\
\hline Baik & 3 & 0 & 0 & 0 \\
$\begin{array}{l}\text { Cukup } \\
\text { Baik }\end{array}$ & 2 & 11 & 11 & 22 \\
Tidak Baik & 1 & 0 & 0 & 0 \\
\hline Total & & 11 & 100 & 22 \\
\hline
\end{tabular}

\section{Rekapitulasi Tupoksi Program Penyuluh Pertanian}

Hasil perhitungan seluruh tupoksi data potensi wilayah, maka disajikan rekapitulasi pada Tabel 13.

Tabel 13. Rekapitulasi Pengukuran Tupoksi Program Penyuluh

\begin{tabular}{lllll}
\multicolumn{2}{c}{ Pertanian } & & & \\
\hline No & $\begin{array}{l}\text { Pernyataan } \\
\text { Tupoksi }\end{array}$ & $\begin{array}{c}\text { Total } \\
\text { Skor }\end{array}$ & $\begin{array}{c}\text { INDEKS } \\
\text { program } \\
\text { penyuluh } \\
\text { pertanian }\end{array}$ & INTERPRESTASI \\
\hline 4 & $\begin{array}{l}\text { Penyusunan } \\
\text { bahan } \\
\text { program }\end{array}$ & 22 & 66,66 & Cukup Baik \\
2 & $\begin{array}{l}\text { Percetakan } \\
\text { materi }\end{array}$ & 22 & 66,66 & Cukup Baik \\
3 & $\begin{array}{l}\text { Pelaksana } \\
\text { program }\end{array}$ & 22 & 66,66 & Cukup Baik \\
\hline
\end{tabular}

Tabel 13 menunjukan bahwa terdapat 3 tupoksi pembentuk program penyuluh pertanian dimana, tupoksi penyusunan bahan program, pencetakan materi dan pelaksanaan program mendapat angka indeks yaitu $66,66 \%$ dengan interpretasi cukup baik.

\section{Terdesiminasinya Info Teknologi Pertanian pada Pelaku Utama}

\section{Penyebaran Informasi}

Pada Tabel 14 menjelaskan tentang tupoksi penyebaran informasi. Hasil penelitian ini menunjukan bahwa $100 \%$ responden (11 orang). Artinya hal ini ditunjukan karena upaya yang dilakukan oleh penyuluh pertanian berusaha memberikan informasi kepada kelompok tani sesuai dengan yang diperoleh penyuluh cukup baik.

\begin{tabular}{lcccc} 
Tabel 14. Penyebaran Informasi \\
\hline $\begin{array}{l}\text { Alternatif } \\
\text { Jawaban }\end{array}$ & $\begin{array}{c}\text { Alternatif } \\
\text { Skor }\end{array}$ & $\begin{array}{c}\text { Jumlah } \\
\text { Responden } \\
\text { (Orang) }\end{array}$ & $\begin{array}{c}\text { Presentase } \\
\text { Responden } \\
\%\end{array}$ & $\begin{array}{c}\text { Total } \\
\text { Skor }\end{array}$ \\
\hline Baik & 3 & 0 & 0 & 0 \\
Cukup Baik & 2 & 11 & 100 & 22 \\
Tidak Baik & 1 & 0 & 0 & 0 \\
\hline Total & & 11 & 100 & 22 \\
\hline
\end{tabular}

Melakukan Kunjungan pada Kelompok Tani Pada Tabel 15 menjelaskan tentang tupoksi melakukan kunjungan kelompok tani. Hasil penelitian ini menunjukan bahwa $100 \%$ responden (11 orang), artinya penyuluh pertanian kurang melakukan kunjungan organisasi kelompok tani, yang seharusnya dilakukan satu minggu satu kali, namun dalam satu bulan melakukan kunjungan hanya satu kali.

\begin{tabular}{lcccc} 
Tabel 15. Melakukan Kunjungan Kelompok Tani & \\
\hline $\begin{array}{l}\text { Alternatif } \\
\text { Jawaban }\end{array}$ & $\begin{array}{c}\text { Alternati } \\
\text { f Skor }\end{array}$ & $\begin{array}{c}\text { Jumlah } \\
\text { Responden } \\
\text { (Orang) }\end{array}$ & $\begin{array}{c}\text { Presentase } \\
\text { Responden } \\
\%\end{array}$ & $\begin{array}{c}\text { Total } \\
\text { Skor }\end{array}$ \\
\hline Baik & 3 & 0 & 0 & 0 \\
Cukup & 2 & 0 & 0 & 0 \\
Baik & 1 & 11 & 100 & 11 \\
Tidak Baik & 11 & 100 & 11 \\
\hline Total & & 11 & &
\end{tabular}

\section{Metode Penerapan Dalam Bentuk Demonstrasi}

Pada Tabel 16 menjelaskan tentang tupoksi melakukan penerapan dalam bentukbentuk demonstrasi. Hasil penelitian ini menunjukan bahwa $100 \%$ responden (11 orang), artinya dalam melakukan metode 
demontrasi, penyuluh masih kurang berkemampuan sehingga ada kelompok tani yang memakai cara alaminya.

\begin{tabular}{lcccc} 
Tabel 16. & $\begin{array}{c}\text { Melaksanakan } \\
\text { Demonstrasi }\end{array}$ & & Metode Penerapan Dalam & Bentuk \\
\hline $\begin{array}{l}\text { Alternatif } \\
\text { Jawaban }\end{array}$ & $\begin{array}{c}\text { Alternatif } \\
\text { Skor }\end{array}$ & $\begin{array}{c}\text { Jumlah } \\
\text { Responden } \\
\text { (Orang) }\end{array}$ & $\begin{array}{c}\text { Presentase } \\
\text { Responden } \\
\%\end{array}$ & $\begin{array}{c}\text { Total } \\
\text { Skor }\end{array}$ \\
\hline $\begin{array}{l}\text { Baik } \\
\text { Cukup }\end{array}$ & 3 & 0 & 0 & 0 \\
$\begin{array}{l}\text { Baik } \\
\text { Tidak }\end{array}$ & 2 & 11 & 100 & 22 \\
Baik & 1 & 0 & 0 & 0 \\
\hline Total & & 11 & 100 & 22 \\
\hline
\end{tabular}

\section{Rekapitulasi Tupoksi Terdesiminasinya Info Teknologi Pertanian Kepala Pelaku Utama}

Hasil perhitungan seluruh tupoksi terdesiminasinya info teknologi pertanian kepada pelaku utama maka disajikan rekapitulasi sebagai berikut. Tabel 17 menunjukan bahwa terdapat 3 indikator pembentuk terdesiminasinya info teknologi pertanian kepada pelaku utama dimana tupoksi penyebaran informasi dan metode penerapan dalam bentuk demonstrasi, mendapat indeks cukup baik yaitu $66,66 \%$ dengan interpretasi cukup baik, sedangkan tupoksi kunjugan tatap muka pada kelompok tani mendapat indeks kurang baik $33,33 \%$ sehingga interpretasi nilainya tergolong tidak baik.

\begin{tabular}{|c|c|c|c|c|}
\hline \multicolumn{2}{|c|}{ Tabel } & $\begin{array}{l}\text { Rekapitulasi } \\
\text { ninasinya Info } \\
\text { Pelaku Utama }\end{array}$ & $\begin{array}{l}\text { Pengukuran } \\
\text { Teknologi }\end{array}$ & \multirow{2}{*}{$\begin{array}{r}\text { Tupoksi } \\
\text { Pertanian } \\
\text { RPRESTASI }\end{array}$} \\
\hline No & TUPOKSI & $\begin{array}{c}\text { TOTAL } \\
\text { SKOR }\end{array}$ & $\begin{array}{c}\text { INDEKS } \\
\%\end{array}$ & \\
\hline 7 & $\begin{array}{l}\text { Penyebaran } \\
\text { informasi }\end{array}$ & 22 & 66,66 & Cukup Baik \\
\hline 8 & $\begin{array}{l}\text { Kunjungan } \\
\text { tatap muka } \\
\text { pada } \\
\text { kelompok } \\
\text { tani }\end{array}$ & 11 & 33,33 & Kurang Baik \\
\hline 9 & $\begin{array}{l}\text { Metode } \\
\text { penerapan } \\
\text { dalam bentuk } \\
\text { demonsrasi }\end{array}$ & 22 & 66,66 & Cukup baik \\
\hline
\end{tabular}

\section{Tumbuh kembangnya Kelembagaan Petani}

\section{Kelompok Tani Kelas Pemula ke Kelompok Tani Kelas Lanjut}

Pada tabel 18 menjelaskan tentang tupoksi dari kelompok tani pemula ke kelas lanjut. hasil penelitian ini menunjukkan bahwa $100 \%$ responden (11 orang), artinya dari tiga kelompok tani ada satu kelompok tani yang naik ke tingkat kelas lanjut.

\begin{tabular}{lcccc} 
Tabel 18. Dari kelompok Tani Pemula ke Kelas Lanjut & \\
\hline $\begin{array}{l}\text { Alternatif } \\
\text { Jawaban }\end{array}$ & $\begin{array}{c}\text { Alternatif } \\
\text { Skor }\end{array}$ & $\begin{array}{c}\text { Jumlah } \\
\text { Responden } \\
\text { (Orang) }\end{array}$ & $\begin{array}{c}\text { Presentase } \\
\text { Responden } \\
\%\end{array}$ & $\begin{array}{c}\text { Total } \\
\text { Skor }\end{array}$ \\
\hline Baik & 3 & 0 & 0 & 0 \\
Cukup Baik & 2 & 11 & 100 & 22 \\
Tidak Baik & 1 & 0 & 0 & 0 \\
\hline Total & & 11 & 100 & 22 \\
\hline
\end{tabular}

\section{Pengembangan Jumlah Kelompok Tani}

Tabel 19 menjelaskan tentang tupoksi dari pengembangan jumlah kelompok tani. Hasil penelitian ini menunjukan bahwa $100 \%$ responden (11 orang), artinya dikarenakan ada tiga kelompok tani yang terbentuk di desa kopiwangker yang awalnya hanya satu kelompok tani dan dari tahun ke tahun kelompok tani meningkat sehingga jumlah kelompok tani menjadi 3 kelompok sampai saat ini.

\begin{tabular}{lcccc}
\multicolumn{6}{l}{ Tabel 19. Pengembangan Jumlah Kelompok Tani } \\
\hline $\begin{array}{l}\text { Alternatif } \\
\text { Jawaban }\end{array}$ & $\begin{array}{c}\text { Alternatif } \\
\text { Skor }\end{array}$ & $\begin{array}{c}\text { Jumlah } \\
\text { Responden } \\
\text { (Orang) }\end{array}$ & $\begin{array}{c}\text { Presentase } \\
\text { Responden } \\
\%\end{array}$ & $\begin{array}{c}\text { Total } \\
\text { Skor }\end{array}$ \\
\hline $\begin{array}{l}\text { Baik } \\
\text { Cukup }\end{array}$ & 3 & 11 & 100 & 33 \\
Baik & 2 & 0 & 0 & 0 \\
Tidak & 1 & 0 & 0 & 0 \\
Baik & & 11 & 100 & 33 \\
\hline Total & & & & \\
\hline
\end{tabular}

\section{Peningkatan Keterampilan Kelompok Tani}

Tabel 20 menjelaskan tentang tupoksi dari kelompok tani pemula ke kelas lanjut. Hasil penelitian ini menunjukan bahwa $100 \%$ responden (11 orang), artinya keterampilan kelompok tani ada yang meningkat dan tidak meningkat, yang awalnya belum mengenal alat mesin pertanian, teknologi pertanian dan sekarang sudah mengenal.

\begin{tabular}{lllll}
\multicolumn{6}{c}{ Tabel 20. Peningkatan Keterampilan Kelompok Tani } & \\
\hline $\begin{array}{c}\text { Alternatif } \\
\text { Jawaban }\end{array}$ & $\begin{array}{c}\text { Alternatif } \\
\text { Skor }\end{array}$ & $\begin{array}{c}\text { Jumlah } \\
\text { Responden } \\
\text { (Orang) }\end{array}$ & $\begin{array}{c}\text { Presentase } \\
\text { Responden } \\
\%\end{array}$ & $\begin{array}{l}\text { Total } \\
\text { Skor }\end{array}$ \\
\hline Baik & 3 & 0 & 0 & 0 \\
Cukup Baik & 2 & 11 & 100 & 22 \\
Tidak Baik & 1 & 0 & 0 & 0 \\
\hline Total & & 11 & 100 & 22 \\
\hline
\end{tabular}

\section{Rekapitulasi Tupoksi Tumbuh Kembanya} Kelembagaan Petani

Hasil perhitungan seluruh tupoksi data potensi wilayah, maka disajikan rekapitulasi sebagai 
berikut. Tabel 21 menunjukan bahwa terdapat 3 indikator pembentuk tumbuh kembangnya kelembagaan petani dimana tupoksi pengembangan jumlah kelompok tani, mendapat indeks baik yaitu $100 \%$ dengan interpretasi baik, sedangkan tupoksi kelompok tani pemula ke lanjut dan peningkatan keterampilan kelompok tani mendapat indeks cukup baik 66,66\% sehingga interpretasi nilainya tergolong cukup baik.

Tabel 21. Rekapitulasi Pengukuran Variabel Tumbuh Kembangya Kelembagaan Petani

\begin{tabular}{ccccc}
\hline No & TUPOKSI & $\begin{array}{c}\text { TOTAL } \\
\text { SKOR }\end{array}$ & $\begin{array}{c}\text { INDEKS } \\
\text { \% }\end{array}$ & INTERPRESTASI \\
\hline 10 & $\begin{array}{l}\text { Kelompok } \\
\text { tani pemula } \\
\text { ke lanjut }\end{array}$ & 22 & 66,66 & Cukup Baik \\
11 & $\begin{array}{l}\text { Pengembang } \\
\text { an jumlah } \\
\text { kelompok } \\
\text { tani }\end{array}$ & 33 & 100 & Baik \\
12 & $\begin{array}{l}\text { Peningkatan } \\
\text { keterampilan } \\
\text { kelompok } \\
\text { tani }\end{array}$ & 22 & 66,66 & Cukup baik \\
\hline
\end{tabular}

\section{Meningkatnya Kapasitas Pelaku Utama}

\section{Jumlah Anggota yang Mengikuti Latihan}

Pada tabel 22 menjelaskan tentang jumlah anggota kelompok tani yang mengikuti pelatihan. Hasil penelitian ini menunjukan bahwa $73 \%$ responden ( 8 orang), mengenai tupoksi jumlah anggota yang mengikuti pelatihan cukup baik, artinya pelatihan yang diikuti oleh pimpinan organisasi cukup baik. Sedangkan $27 \%$ responden (3 orang) menyatakan bahwa tupoksi jumlah anggota yang mengikuti pelatihan berkategori tidak baik karena hanya di ikuti oleh salah satu pimpinan dan pelatihan jarang di lakukan.

Tabel 22. Jumlah Anggota Kelompok Tani yang Mengikuti

\begin{tabular}{|c|c|c|c|c|}
\hline $\begin{array}{l}\text { Alternatif } \\
\text { Jawaban }\end{array}$ & $\begin{array}{c}\text { Alternatif } \\
\text { Skor }\end{array}$ & $\begin{array}{c}\text { Jumlah } \\
\text { Responden } \\
\text { (Orang) }\end{array}$ & $\begin{array}{c}\text { Presentase } \\
\text { Responden } \\
\%\end{array}$ & $\begin{array}{l}\text { Total } \\
\text { Skor }\end{array}$ \\
\hline Baik & 3 & 0 & 0 & 0 \\
\hline Cukup Baik & 2 & 8 & 73 & 16 \\
\hline Tidak Baik & 1 & 3 & 27 & 19 \\
\hline Total & & 11 & 100 & 19 \\
\hline
\end{tabular}

\section{Peningkatan Kualitas dan Kuantitas Demplot}

Pada tabel 23 menjelaskan tentang peningkatan kualitas dan kuantitas demplot. Hasil penelitian ini menunjukan bahwa $100 \%$ responden (11 orang), artinya upaya yang dilakukan penyuluh cukup baik sehingga petani bisa menerapkan yang diberikan penyuluh pertanian.

\begin{tabular}{lcccc} 
Tabel 23. Peningkatan Kualitas Dan Kualitas Demplot & \\
\hline $\begin{array}{l}\text { Alternatif } \\
\text { Jawaban }\end{array}$ & $\begin{array}{c}\text { Alternatif } \\
\text { Skor }\end{array}$ & $\begin{array}{c}\text { Jumlah } \\
\text { Responden } \\
\text { (Orang) }\end{array}$ & $\begin{array}{c}\text { Presentase } \\
\text { Responden } \\
\%\end{array}$ & $\begin{array}{c}\text { Total } \\
\text { Skor }\end{array}$ \\
\hline Baik & 3 & 0 & 0 & 0 \\
Cukup Baik & 2 & 11 & 100 & 22 \\
Tidak Baik & 1 & 0 & 0 & 0 \\
\hline Total & & 11 & 100 & 22 \\
\hline
\end{tabular}

\section{Peningkatan Kesejahteraan Petani}

Pada tabel 24 menjelaskan tentang peningkatan kesejahteraan petani. Hasil penelitian ini menunjukan bahwa 100\% responden (11orang), artinya untuk kesejahteraan kelompok tani di lihat dari ekonomi yang cukup mengalami peningkatan setelah mengenal teknologi pertanian.

\begin{tabular}{lcccc}
\multicolumn{5}{l}{ Tabel 24. Peningkatan Kesejahteraan Petani } \\
\hline Alternatif & $\begin{array}{c}\text { Alternatif } \\
\text { Skor }\end{array}$ & $\begin{array}{c}\text { Jumlah } \\
\text { Responden } \\
\text { (Orang) }\end{array}$ & $\begin{array}{c}\text { Presentase } \\
\text { Responden } \\
\%\end{array}$ & $\begin{array}{c}\text { Total } \\
\text { Skor }\end{array}$ \\
\hline Baik & 3 & 0 & 0 & 0 \\
Cukup Baik & 2 & 11 & 100 & 22 \\
Tidak Baik & 1 & 0 & 0 & 0 \\
\hline Total & & 11 & 100 & 22 \\
\hline
\end{tabular}

\section{Rekapitulasi Variabel Meningkatnya Kapasitas Pelaku Utama}

Hasil perhitungan seluruh tupoksi meningkatkan pelaku utama, maka disajikan rekapitulasi pada Tabel 25 .

\begin{tabular}{ccccc}
$\begin{array}{c}\text { Tabel 25. Rekapitulasi } \\
\text { Kapasitas } \\
\text { Pelaku Utama }\end{array}$ & Pengukuran & Tupoksi & Meningkatnya \\
\hline No & TUPOKSI & $\begin{array}{c}\text { TOTA } \\
\text { L } \\
\text { SKOR }\end{array}$ & $\begin{array}{c}\text { INDEKS } \\
\%\end{array}$ & $\begin{array}{c}\text { INTERPRESTA } \\
\text { SI }\end{array}$ \\
\hline 13 & $\begin{array}{l}\text { Jumlah anggota } \\
\text { yang mengikuti } \\
\text { pelatihan }\end{array}$ & 19 & 57,57 & Cukup Baik \\
14 & $\begin{array}{l}\text { Peningkatan } \\
\text { kualitas dan } \\
\text { kuantitas } \\
\text { demplot }\end{array}$ & 22 & 66,66 & Cukup Baik \\
15 & $\begin{array}{l}\text { Peningkatan } \\
\text { kesejahteraan } \\
\text { petani }\end{array}$ & 22 & 66,66 & Cukup baik \\
\hline
\end{tabular}

Tabel 25 menunjukan bahwa terdapat 3 indikator meningkatkan kapasitas pelaku utama dimana tupoksi peningkatan kualitas dan kuantitas demplot dan peningkatan kesejahteraan petani mendapat indeks baik yaitu $66,66 \%$ dengan interpretasi cukup baik, sedangkan tupoksi jumlah 
anggota yang mengikuti pelatihan mendapat indeks cukup baik $57,57 \%$ sehingga interpretasi nilainya tergolong cukup baik.

\section{Meningkatnya Akses Pelaku Utama Terhadap Info Pasar, teknologi da Pembiayaan}

\section{Pembentukan Jejaring Antar Kerja Kelompok Tani}

Pada tabel 26 menjelaskan tentang tupoksi pembentukan jejaring antar kelompok tani. Hasil penelitian ini menunjukan bahwa $73 \%$ responden ( 8 orang) ,artinya tugas penyuluh dalam hal membangun kerjasama antar petani baik, karena setiap anggota kelompok tani saling membutuhkan dan $27 \%$ responden menyatakan bahwa kurangnya kerja dari penyuluh dalam membangun kerjasama, karena terbentuknya kerjasama antar kelompok tercipta dengan kerja dari kelompok sendiri.

\begin{tabular}{lcccc} 
Tabel 26. & Pembentuk Jejaring Antar Kerja Kelompok Tani \\
\hline $\begin{array}{l}\text { Alternatif } \\
\text { Jawaban }\end{array}$ & $\begin{array}{c}\text { Alternatif } \\
\text { Skor }\end{array}$ & $\begin{array}{c}\text { Jumlah } \\
\text { Responden } \\
\text { (Orang) }\end{array}$ & $\begin{array}{c}\text { Presentase } \\
\text { Responden } \\
\%\end{array}$ & $\begin{array}{c}\text { Total } \\
\text { Skor }\end{array}$ \\
\hline Baik & 3 & 8 & 73 & 24 \\
Cukup Baik & 2 & 0 & 0 & 0 \\
Tidak Baik & 1 & 3 & 27 & 3 \\
\hline Total & & 11 & 100 & 27
\end{tabular}

\section{Memberi Informasi Pasar}

Pada tabel 27 menjelaskan tentang tupoksi memberi informasi pasar Hasil penelitian ini menunjukkan bahwa $73 \%$ responden ( 8 orang), mengenai tupoksi memberi informasi pasar berkategori cukup baik, artinya kelompok tani mendapat informasi dalam hal ini harga pasar dan jumlah kebutuhan pasar. Sedangkan 27\% (3 orang) berkategori tidak baik karena kelompok tani mendapat informasi terlebih dahulu.

\begin{tabular}{lcccc} 
Tabel 27. Memberi Informasi & Pasar \\
\hline Alternatif & $\begin{array}{c}\text { Alternatif } \\
\text { Jawaban }\end{array}$ & $\begin{array}{c}\text { Jumlah } \\
\text { Responden } \\
\text { (Orang) }\end{array}$ & $\begin{array}{c}\text { Presentase } \\
\text { Responden } \\
\%\end{array}$ & $\begin{array}{c}\text { Total } \\
\text { Skor }\end{array}$ \\
\hline Baik & 3 & 0 & 0 & 0 \\
Cukup Baik & 2 & 8 & 73 & 16 \\
Tidak Baik & 1 & 3 & 27 & 3 \\
\hline Total & & 11 & 100 & 19 \\
\hline
\end{tabular}

\section{Pengembangan Kemitraan}

Pada tabel 28 menjelaskan tentang tupoksi pengembangan kemitraan Hasil penelitian ini menunjukan bahwa $100 \%$ responden (11 orang), artinya upaya yang dilakukan oleh penyuluh pertanian dalam hal membangun kerjasama dengan pihak luar baik sehingga pelaku utama akan mudah bekerjasama dengan lainnya dan membuat perjanjian tertulis atau kesepakatan.

\begin{tabular}{lcccc} 
Tabel 28. Pengembangan Kemitraan & & \\
\hline $\begin{array}{l}\text { Alternatif } \\
\text { Jawaban }\end{array}$ & $\begin{array}{c}\text { Alternatif } \\
\text { Skor }\end{array}$ & $\begin{array}{c}\text { Jumlah } \\
\text { Responden } \\
\text { (Orang) }\end{array}$ & $\begin{array}{c}\text { Presentase } \\
\text { Responden } \\
\%\end{array}$ & $\begin{array}{c}\text { Total } \\
\text { Skor }\end{array}$ \\
\hline Baik & 3 & 11 & 100 & 33 \\
Cukup Baik & 2 & 0 & 0 & 0 \\
Tidak Baik & 1 & 0 & 0 & 0 \\
\hline Total & & 11 & 100 & 33 \\
\hline
\end{tabular}

\section{Rekapitulasi Tupoksi Meningkatnya Akses Pelaku Utama Pada Info Pasar, Teknologi dan Pembiayaan}

Hasil perhitungan seluruh tupoksi data meningkatkan akses pelaku utama terhadap informasi pasar, teknologi dan pembiyaan, maka disajikan rekapitulasi sebagai berikut. Tabel 29 menunjukan bahwa terdapat 3 tupoksi meningkatnya akses terhadap informasi pasar teknologi dan pembiayaan dimana pernyataan pengembangan kemitraan mendapat indeks $100 \%$, dengan interpretasi nilainya tergolong baik, dan tupoksi pembentukan jejaring antar kerja kelompok tani mendapat indeks $81.81 \%$ dengan interpretasi nilainya tergolong baik, dan tupoksi memberi informasi pasar mendapat indeks yaitu $57,57 \%$ dengan interpretasi cukup baik.

\begin{tabular}{|c|c|c|c|c|}
\hline No & Tupoksi & $\begin{array}{l}\text { Total } \\
\text { Skor }\end{array}$ & $\begin{array}{c}\text { Indeks } \\
\text { Kinerja }\end{array}$ & Interpretasi \\
\hline 16 & $\begin{array}{l}\text { Pembentuk jejaring antar } \\
\text { kerja kelompok tani }\end{array}$ & 27 & $81,, 81$ & Baik \\
\hline 17 & Memberi informasi pasar & 19 & 57,57 & Cukup Baik \\
\hline 18 & $\begin{array}{l}\text { Peningkatan pendapatan } \\
\text { keluarga kelompok tani }\end{array}$ & 33 & 100 & Baik \\
\hline
\end{tabular}

\section{Meningkatnya Produksi dan Meningkatnya Pendapatan Pelaku Utama}

\section{Peningkatan Produksi}

Pada tabel 30 menjelaskan tentang peningkatan produksi. Hasil penelitian ini menunjukan bahwa $100 \%$ responden (11 orang), artinya terjadi peningkatan produksi pada usaha tani kelompok tani dari tahun ke tahun terjadi peningkatan produksi meski tidak mencapai target.

\begin{tabular}{lcccc}
\multicolumn{6}{l}{ Tabel 30. Peningkatan Produksi } \\
\hline Alternatif & $\begin{array}{c}\text { Alternatif } \\
\text { Jawaban }\end{array}$ & $\begin{array}{c}\text { Jumlah } \\
\text { Responden } \\
\text { (Orang) }\end{array}$ & $\begin{array}{c}\text { Presentase } \\
\text { Responden } \\
\%\end{array}$ & $\begin{array}{c}\text { Total } \\
\text { Skor }\end{array}$ \\
\hline Baik & 3 & 0 & 0 & 0 \\
Cukup Baik & 2 & 11 & 100 & 22 \\
Tidak Baik & 1 & 0 & 0 & 0 \\
\hline Total & & 11 & 100 & 22 \\
\hline
\end{tabular}




\section{Peningkatan Pendapatan Kelompok Tani}

Pada tabel 31 menjelaskan tentang tupoksi peningkatan pendapatan kelompok tani. Hasil penelitian ini menunjukan bahwa $100 \%$ responden (11 orang), artinya berhubung terjadi peningkatan produksi pada usaha tani kelompok tani tentu pendapatan kelompok tani ada peningkatan.

\begin{tabular}{lcccc}
\multicolumn{6}{l}{ Tabel 31. Peningkatan Pendapatan Kelompok Tani } \\
\hline Alternatif & $\begin{array}{c}\text { Alternatif } \\
\text { Skwaban }\end{array}$ & $\begin{array}{c}\text { Jumlah } \\
\text { Responden } \\
\text { (Orang) }\end{array}$ & $\begin{array}{c}\text { Presentase } \\
\text { Responden } \\
\%\end{array}$ & $\begin{array}{c}\text { Total } \\
\text { Skor }\end{array}$ \\
\hline Baik & 3 & 0 & 0 & 0 \\
Cukup Baik & 2 & 11 & 100 & 22 \\
Tidak Baik & 1 & 0 & 0 & 0 \\
\hline Total & & 11 & 100 & 22 \\
\hline
\end{tabular}

\section{Peningkatan Pendapatan Keluarga \\ Kelompok Tani}

Pada tabel 32 menjelaskan tentang tupoksi peningkatan pendapatan keluarga kelompok tani. Hasil penelitian ini menunjukan bahwa $100 \%$ responden (11 orang), artinya setiap keluarga tani merasakan dampak peningkatan dari hasil pertanian dari kelompok tani.

Tabel 32. Peningkatan Pendapatan Keluarga Kelompok Tani

\begin{tabular}{lcccc}
\hline $\begin{array}{l}\text { Alternatif } \\
\text { Jawaban }\end{array}$ & $\begin{array}{c}\text { Alternatif } \\
\text { Skor }\end{array}$ & $\begin{array}{c}\text { Jumlah } \\
\text { Responden } \\
\text { (Orang) }\end{array}$ & $\begin{array}{c}\text { Presentase } \\
\text { Responden } \\
\%\end{array}$ & $\begin{array}{c}\text { Total } \\
\text { Skor }\end{array}$ \\
\hline Baik & 3 & 0 & 0 & 0 \\
Cukup & 2 & 11 & 100 & 22 \\
$\begin{array}{l}\text { Baik } \\
\text { Tidak }\end{array}$ & 1 & 0 & 0 & 0 \\
Baik & & 11 & 100 & 22 \\
\hline Total & & & & \\
\hline
\end{tabular}

\section{Rekapitulasi Tupoksi Meningkatnya Produksi dan Pendapatan Pelaku Utama}

Hasil perhitungan seluruh tupoksi meningkatnya produksi dan pendapatan pelaku utama, maka disajikan rekapitulasi sebagai berikut. Tabel 33 menunjukan bahwa terdapat 3 indikator meningkatnya produksi dan pendapatan pelaku utama dimana tupoksi peningkatan produksi, peningkatan pendapatan kelompok tani dan tupoksi peningkatan pendapatan keluarga kelompok tani mendapat angka indeks yaitu $66,66 \%$ sehinngga interpretasi nilainya tergolong cukup baik.
Tabel. 33 Rekapitulasi Pengukuran Tupoksi Meningkatnya Produksi dan Pendapatan Pelaku Utama

\begin{tabular}{ccccc} 
No & TUPOKSI & $\begin{array}{c}\text { TOTAL } \\
\text { SKOR }\end{array}$ & $\begin{array}{c}\text { INDEKS } \\
\%\end{array}$ & INTERPRESTASI \\
\hline 19 & $\begin{array}{l}\text { Peningkatan } \\
\text { produksi }\end{array}$ & 22 & 66,66 & Cukup Baik \\
20 & $\begin{array}{l}\text { Peningkatan } \\
\text { pendapatan } \\
\text { kelompok } \\
\text { tani }\end{array}$ & 22 & 66,66 & Cukup Baik \\
21 & $\begin{array}{l}\text { Peningkatan } \\
\text { keterampilan } \\
\text { kelompok } \\
\text { tani }\end{array}$ & 22 & 66,66 & Cukup baik \\
\hline
\end{tabular}

Rekapitulasi Indeks Kinerja Penyuluh Pertanian Pada Kelompok tani Padi Sawah Masing-masing Tupoksi dan Interprestasi hasil

Hasil perhitungan seluruh tupoksi meningkatnya produksi dan pendapatan. Tabel 34 tersebut, tupoksi menemukan potensi wilayah dan tupoksi melakukan kunjungan atau tatap muka mendapatkan hasil yang terendah dari 21 indikator lainnya, hal ini di karenakan tupoksi menemukankan potensi wilayah mendapat indeks $33,33 \%$ yang tergolong tidak baik, karena untuk menemukan potensi wilayah yang seharusnya ditemukan oleh penyuluh pertanian, namun ditemukan oleh kelompok tani sendiri, dan tupoksi melakukan kunjungan atau tatap muka mendapat indeks 33,33\% yang tergolong tidak baik, karena kelompok tani melihat dalam hal untuk melakukan kunjungan pada organisasi kelompok tani penyuluh kurang melakukan tugasnya.

Selanjutnya tupoksi pengembagan jumlah kelompok tani mendapat indeks $100 \%$ yang tergolong baik, artinnya ada tiga kelompok tani yang terbentuk di desa kopiwangker yang awalnya hanya satu kelompok tani dan sekarang menjadi tiga kelompok, selanjutnya tupoksi pengembangan kemitraan mendapatkan hasil tertinggi dengan indeks $100 \%$ yang tergolong baik, artinya upaya yang dilakukan oleh penyuluh pertanian dalam hal membangun kerjasama denga pihak luar baik sehingga pelaku utama akan mudah bekerja sama dengan lainnya. Dan tupoksi pembentukan jejaring antar kerja kelompok tani mendaptkan indek $81,81 \%$ yang tergolong baik, artinya tugas penyuluh dalam hal membangun kerjasama antar petani baik, karena setiap anggota kelompok tani saling membutuhkan. Hasil untuk mengetahui kinerja dari penyuluh 
pertanian pada kelompok tani maka perlu dihitung jumlah keseluruhan skor pada setiap kriterium. Jumlah skor hasil penelitian ini mencapai 461. Pada penelitian ini jumlah skor ideal (skor tertinggi) adalah 639 (tinggi) dan jumlah skor terendah yaitu 231 (rendah). Berdasarkan data yang diambil dari 21 tupoksi yang diajukan pada 11 responden, maka letak indeks kinerja penyuluh pada kelompok tani padi sawah terletak pada:

Tingkat Kinerja Penyuluh Pertanian = $\frac{\text { Jumlah Skor Hasil Pengumpulan Data }}{\text { Jumlah Skor Ideal (tertinggi) }} \times 100 \%$

Tingkat Kinerja Penyuluh Pertanian $=\frac{461}{693} \times 100 \%=66,52 \%$

Dengan interpretasi nilai :

0

$$
33,33 \% \quad 66,66 \%
$$

$100 \%$

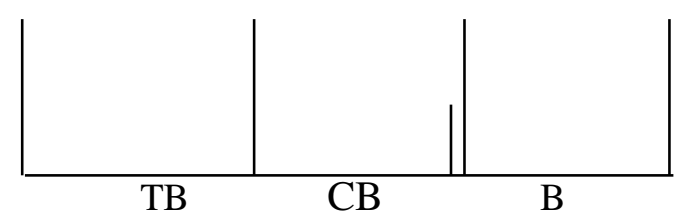

Keterangan kriteria interpretasi skor :

Angka 0\%-33.33\% = Tidak Baik

Angka 33.33\%-66.66\% = Cukup Baik

Angka 66.66\%-100\% = Baik

\section{Hasil perhitungan}

diatas

menunjukan angka indeks kinerja penyuluh pertanian pada Kelompok Tani Padi Sawah di Desa Kopiwangker Kecamatan Langowan Barat $66,52 \%$, artinya penyuluh pertanian secara umum tergolong cukup baik karena dilihat dari 21 tupoksi dimana 3 tupoksi dikategorikan baik, 16 tupoksi cukup baik, dan 2 tupoksi tidak baik. Kinerja dari penyuluh pertanian pada wilayah binaan perlu ditingkatakan, maka penyuluh pertanian harus memperhatikan tugas dan fungsi penyuluh pada ketujuh tupoksi di atas yaitu: data potensi, program penyuluhan pertanian, terdesiminasinya info teknologi pertanian, tumbuh kembangnya kelembagaan petani, meningkatnya kapasitas pelaku utama, meningkatnya akses pelaku utama terhadap informasi pasar, teknologi dan pembiayaan, meningkatnya produksi dan pendapatan pelaku utama.

\begin{tabular}{|c|c|c|c|c|}
\hline & Kelompok & awah & & \\
\hline No & Tupoksi & $\begin{array}{l}\text { Total } \\
\text { Skor }\end{array}$ & $\begin{array}{c}\text { Indeks } \\
\text { Kinerja }\end{array}$ & Interpretasi \\
\hline 1. & $\begin{array}{l}\text { Menemukan potensi } \\
\text { Wilayah }\end{array}$ & 11 & 33,33 & Tidak Baik \\
\hline 2. & $\begin{array}{l}\text { Pembuatan Peta Wilayah } \\
\text { Kerja }\end{array}$ & 22 & 66,66 & Cukup Baik \\
\hline 3. & $\begin{array}{l}\text { Keterlibatan dalam } \\
\text { Potensi }\end{array}$ & 22 & 66,66 & Cukup Baik \\
\hline 4. & $\begin{array}{l}\text { Penyusunan Bahan } \\
\text { Program }\end{array}$ & 22 & 66,66 & Cukup Baik \\
\hline 5. & Pencetakan Materi & 22 & 66,66 & Cukup Baik \\
\hline 6. & Pelaksanaan Program & 22 & 66,66 & Cukup Baik \\
\hline 7. & Penyebaran Informasi & 22 & 66,66 & Cukup Baik \\
\hline 8. & $\begin{array}{l}\text { Melakukan } \\
\text { Kunjungan/tatap muka }\end{array}$ & 11 & 33,33 & Tidak Baik \\
\hline 9. & $\begin{array}{l}\text { Melaksanakan Metode } \\
\text { Penerapan dalam Bentuk } \\
\text { Demonstrasi }\end{array}$ & 22 & 66,66 & Cukup Baik \\
\hline 10. & $\begin{array}{l}\text { Dari Kelompok Tani } \\
\text { Pemula ke Kelas Lanjut }\end{array}$ & 22 & 66,66 & Cukup Baik \\
\hline 11. & $\begin{array}{l}\text { Pengembangan Jumlah } \\
\text { Kelompok Tani }\end{array}$ & 33 & 100 & Baik \\
\hline 12. & $\begin{array}{l}\text { Peningkatan } \\
\text { Keterampilan Kelompok } \\
\text { Tani }\end{array}$ & 22 & 66,66 & Cukup Baik \\
\hline 13. & $\begin{array}{l}\text { Jumlah Anggota yang } \\
\text { mengikuti Pelatihan }\end{array}$ & 19 & 57,57 & Cukup Baik \\
\hline 14. & $\begin{array}{l}\text { Peningkatan Kualitas dan } \\
\text { Kuantitas Demplot }\end{array}$ & 22 & 66,66 & Cukup Baik \\
\hline 15. & $\begin{array}{l}\text { Peningkatan } \\
\text { Kesejahteraan Petani }\end{array}$ & 22 & 66,66 & Cukup Baik \\
\hline 16. & $\begin{array}{l}\text { Pembentukan Jejaring } \\
\text { antar kerja Kelompok } \\
\text { Tani }\end{array}$ & 27 & 81,81 & Baik \\
\hline 17. & Memberi Informasi Pasar & 19 & 57,57 & Cukup Baik \\
\hline 18. & Pengembangan Kemitraan & 33 & 100 & Baik \\
\hline 19. & Peningkatan Produksi & 22 & 66,66 & Cukup Baik \\
\hline 20. & Peningkatan Pendapatan & 22 & 66,66 & Cukup Baik \\
\hline 21. & $\begin{array}{l}\text { Peningkatan Pendapatan } \\
\text { keluarga Tani }\end{array}$ & 22 & 66,66 & Cukup Baik \\
\hline
\end{tabular}

Tabel. 34 Rekapitulasi Indeks Kinerja Penyuluh Pertanian pada

\section{KESIMPULAN DAN SARAN}

\section{Kesimpulan}

Hasil penelitian menunjukan bahwa tingkat kinerja penyuluh pertanian pada kelompok tani Di Desa Kopiwangker tergolong cukup baik karena dilihat dari 21 tupoksi dimana 3 tupoksi dikategorikan baik, 16 tupoksi cukup baik, dan 2 tupoksi tidak baik. Kinerja dari penyuluh pertanian pada wilayah binaan perlu ditingkatkan, maka penyuluh pertanian harus memperhatikan tugas dan fungsi penyuluh pada ketujuh tupoksi di atas yaitu: data potensi, program penyuluhan pertanian, terdesiminasinya info teknologi pertanian, tumbuh kembangnya kelembagaan petani, meningkatnya kapasitas pelaku utama, meningkatnya akses pelaku utama terhadap informasi pasar, teknologi dan 
pembiayaan, meningkatnya produksi dan pendapatan pelaku utama.

\section{Saran}

Kinerja dari penyuluh pertanian pada wilayah binaan perlu untuk ditingkatkan, maka penyuluh pertanian harus memperhatikan tugas dan fungsi penyuluh pada ketujuh tupoksi di atas yaitu: data potensi, program penyuluhan pertanian, terdesiminasi info pada pelaku utama, tumbuh kembangnya kelembagaan petani, meningkatnya kapasitas pelaku utama, meningkatnya akses pelaku utama terhadap informasi pasar, teknologi dan pembiayaan, meningkatnya produksi dan pendapatan pelaku utama. Perlu adanya peningkatan kinerja dari penyuluh pertanian terhadap kelompok tani. Dan diharapkan dapat mengupayakan tenaga penyuluh pertanian karena menggigat wilayah kerja dan kelompok tani yang harus dibina di BP3K Kecamatan Langowan Barat wilayah luas dan terdapat banyak kelompok tani.

\section{DAFTAR PUSTAKA}

BP3K, Kecamatan Langowan Barat.2016.

Departemen Pertanian, 2007. Pedoman Pembinaan Kelembagaan Petani.

Departemen Pertanian, 2008. Kertas Kerja Kelompok Tani.

Hartono C, 2001. Konsep Kinerja. Diakses 15 Oktober 2016.

Kartasapoetra, A, G, 1994. Teknologi Penyuluhan Pertanian. Bumi Aksara, Jakarta.

Mardikanto, 2003. Penyuluhan
Pembangunan
Surakarta.

Mardikanto, T. 2003, Modal Sosial bagi masyarakat petani, Rineka Cipta Jakarta.

Mardikanto, T. 1993. Penyuluhan Pembangunan Pertanian. Surakarta: Sebelas Maret University Press.

Samsudin, 1993. Tinjauan Struktur Kelompok Tani. Penerbit Bina Cipta. Bandung.

Saragih B, 2006. Penyuluh Pertanian. Penerbit Yayasan Pengembangan Sinar Tani. CV Rajawali Jakarta.

Sunyoto Danang. 2012. Konsep Dasar Riset Pemasaran \& Perilaku Konsumen

Suwandi, Achmad. 2006. Administrasi Penyuluh Pertanian. Universitas Terbuka Jakarta.

Suprayono dan Setyono, 1993. Padi. Penebar Swadaya. Jakarta. Diakses 6 Oktober 2016.

Simamora, 2003. Penilaian Kinerja dalam Manajemen Perusahaan. Jakarta: Gramedia Pustaka.

Tangkulung, Christi. 2015. Analisis Kepuasan Konsumen Terhadap Atribut Sayuran Organik di Hypermart Manado. Skripsi Jurusan Sosial Ekonomi Fakultas Pertanian Unsrat Manado.

Taufiq, M, A.,2007.Definisi Kinerja. Diakses 12 Oktober. 